\title{
Energy subsidy and oil price fluctuation, and price behavior in Malaysia:A time series analysis
}

\author{
Dzul Hadzwan Husaini a , Chin-Hong Puah a, Hooi Hooi Lean b, *

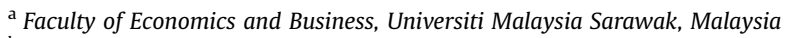 \\ ${ }^{\mathrm{b}}$ Economics Program, School of Social Sciences, Universiti Sains Malaysia, Malaysia
}

\section{A R T I C L E I N F O}

\section{Article history:}

Received 2 June 2018

Received in revised form

5 January 2019

Accepted 14 January 2019

Available online 18 January 2019

\section{JEL classification:}

Q43

Keywords:

Energy subsidy

Oil price

Price behavior

Malaysia

\begin{abstract}
A B S T R A C T
Balancing between favorable energy subsidy and the financial burden of government is crucial for policymakers. This article intends to advance this thinking by informing policymakers about how price reacts to changes in the international oil price and energy subsidy program. Hence, it is essential to investigate the empirical evidence concerning the relationship between the international oil price and energy subsidy, and price behavior. This study used time series data covering the period 1981-2015 to explore the price behavior on energy subsidy rationalization and oil price fluctuation in Malaysia. To prepare concrete empirical evidence, we employed the autoregressive distribution lag (ARDL) approach to capture the long-run dynamic behavior. Our findings indicated that both factors, oil price and energy subsidy, are significant in influencing the pattern of price behavior. The PPI (Producer Price Index) was more sensitive to changes in the oil price than the CPI (Consumer Price Index). The PPI was found to be affected more while the CPI was less affected. We call on policymakers to provide the Malaysian economic system with a productive social safety net to offset the negative impact caused by energy subsidy reform.
\end{abstract}

() 2019 Published by Elsevier Ltd.

\section{Introduction}

The impact of oil price fluctuations on price has become one of the most attractive areas of study in current literature. It has been mentioned in many economic reports and articles that oil price fluctuations have significantly influenced price [1,2,3-6,53]. An increase in price will consequently reduce any consumer surplus. In the microeconomic view, any loss of consumer surplus can be used to indicate a decrease in economic welfare in an economy, which reflects the high cost of living in a society $[7,8]$. Thus, it has become a crucial area that needs to be addressed by policymakers, especially to achieve objectives in the political economy. Basically, oil price is closely related to price behavior due to several points of understanding from the economic perspective. First, oil is considered to be the main energy commodity used in economic activities, especially for economic production. In the global perspective, about $80.8 \%$ of total energy consumption is from oil consumption (World Development Indicator, 2017). A high dependency on oil in an

\footnotetext{
* Corresponding author. Economics Program, School of Social Sciences, Universiti Sains Malaysia, 11800, USM, Penang, Malaysia.

E-mail address: hooilean@usm.my (H.H. Lean).
}

economy leads price to be sensitive when responding to the pattern of oil price fluctuations. Second, the impact of oil price fluctuations varies across countries. It might have a different impact on the economic performance of oil producing countries and non-oil producing countries. Furthermore, not all oil-producing countries are net oil exporting economies. It also has a different impact on oil price fluctuations on price between net oil exporting economies and net importing economies.

As a net oil exporting country, Malaysia produced about 30.3 million tons of crude oil and the total net energy import was valued at $-6 \%$ of energy use in 2014 [57,58] (WDI, 2017). Malaysia was ranked 25th among the oil-producing economies in the world with a value of $-6 \%$ of energy use for net energy import with oil revenue earning being about 3.5\% of GDP in 2014. The Malaysian economy is very sensitive to world oil price fluctuations. Tellingly, Malaysia values about $44 \%$ of energy imports out of the total oil consumption and the government spent about $56 \%$ of total subsidies on fossil fuel energy consumption in 2014 (Ministry of Finance Malaysia, 2015; [55]). In addition, $20 \%$ of Malaysia's national income was contributed from oil revenue in 2014 [56]. Thus, large increases in the oil price cause Malaysia to suffer from a high oil price as an oil importer together with increased fiscal pressure due to high 